\title{
THERMAL ANNEALING OF WWER - 440 NUCLEAR REACTOR PRESSURE VESSEL INTERNALS MATERIAL
}

\author{
Ivana SCHNABLOVÁ ${ }^{1}$, Radim KOPŘIVA ${ }^{1}$, Ondřej BURŠíK ${ }^{1}$, Kateřina RUSŇÁKOVÁ ${ }^{1}$, \\ Aleš MATERNA ${ }^{2}$ \\ 1UJV Rez, a.s., Husinec, Czech Republic, EU, ivana.schnablova@ujv.cz, radim.kopriva@ujv.cz, \\ ondrej.bursik@ujv.cz, katerina.rusnakova@ujv.cz \\ ${ }^{2}$ Czech Technical University in Prague, Faculty of nuclear Sciences and Physical engineering, Prague, \\ Czech Republic, EU, ales.materna@ffifi.cz
}

https://doi.org/10.37904/metal.2020.3497

\begin{abstract}
Current trend of long-term operation of NPP's for more than 60 years requires assurance of its safety and reliability. One of the solutions how to extend service life of reactor pressure vessel (RPV) is thermal annealing, which became a verified technology and its application in nuclear industry was prompted mainly due to an inability of RPV exchange. At present time, there is no comparable method for RPV internals that are not monitored by surveillance program and their material is exposed to significantly more intense neutron flux than the RPV. Paper presents the thermal annealing as one of the possible solutions to provide and re-establish sufficient mechanical properties of RPV internals during the operation. According to previously obtained results of unirradiated material, two thermal annealing regimes for irradiated experimental material were selected based on the annealing temperatures of 550 and $600^{\circ} \mathrm{C}$. The possibility of recovery of mechanical properties to the level almost corresponding to the initial state by the thermal annealing was studied by hardness testing and static fracture toughness tests before and after the thermal annealing of irradiated material.
\end{abstract}

Keywords: Thermal annealing, austenitic stainless steel, reactor pressure vessel internals

\section{INTRODUCTION}

The reactor internals function is to support the core, to hold the fuel assemblies in place, to direct coolant flow, to hold and protect control rods in normal operation conditions and accident conditions. The reactor internals are designed to ensure cooling of the fuel, to ensure the movement of control rods under all operating conditions including accidents and facilitate removal of the fuel and of the internals proper following and accident $[1,2]$. The main components of the WWER reactor internals are the core barrel, the core shroud (core basket for WWER - 440) at the level of the core and the block of guide tubes. These components are fixed together and to the reactor vessel in a way, that allows their withdrawal, inspection, and partial repair as well as inspection of the reactor pressure vessel inner surface. The WWER reactor pressure internals are manufactured assembled and installed in line with requirements of the respective standards and quality control and assurance procedures [1,2].

The main structural material for the WWER - 440 reactor internals is corrosion resistant titanium stabilized austenitic stainless steel 08Kh18N10T. Corrosion resistant 08Kh18N10T austenitic stainless steel (ASTM equivalent AISI 321) is chromium - nickel steel stabilized with titanium to prevent carbide precipitation and designed to work within the temperature range, where carbide precipitation can develop [3]. The aim of the project TH02020565 is to design several thermal annealing regimes and to demonstrate their application to unirradiated and irradiated materials. Mechanical properties evaluation of unirradiated specimen before and after annealing treatment (hardness tests) is necessary. In the next part of this project, mechanical properties, 
evaluation of irradiated specimens after annealing treatment (hardness tests, static fracture toughness of miniaturized compact test) were tested.

\section{MATERIALS AND METHODS}

\subsection{Material}

Testing specimens for the experimental program were made from the unirradiated and irradiated corrosion resistant austenitic stainless steel 08Kh18N10T. The chemical composition of the unirradiated austenitic stainless steel 08Kh18N10T is shown in Table 1. Irradiated materials used in this research program have its origin in Greifswald nuclear power plant (WWER 440) which had been closed after 15 years of service (Table 2).

Table 1 Chemical composition of the corrosion resistant austenitic stainless steel 08Kh18N10T

\begin{tabular}{|ccccccccccccccccc|}
\hline $\mathbf{C}$ & $\mathbf{M n}$ & $\mathbf{S i}$ & $\mathbf{P}$ & $\mathbf{S}$ & $\mathbf{C r}$ & $\mathbf{N i}$ & $\mathbf{C u}$ & $\mathbf{M o}$ & $\mathbf{A l}$ & $\mathbf{T i}$ & $\mathbf{V}$ & $\mathbf{N b}$ & $\mathbf{N}$ & $\mathbf{W}$ & $\mathbf{C o}$ & $\mathbf{H}$ \\
$\%$ & $\%$ & $\%$ & $\%$ & $\%$ & $\%$ & $\%$ & $\%$ & $\%$ & $\%$ & $\%$ & $\%$ & $\%$ & $\mathrm{ppm}$ & $\%$ & $\%$ & $\mathrm{ppm}$ \\
$\mathbf{0 . 0 5}$ & $\mathbf{1 . 6 6}$ & $\mathbf{0 . 5 2}$ & $\mathbf{0 . 0 3 1}$ & $\mathbf{0 . 0 0 5}$ & $\mathbf{1 7 . 5}$ & $\mathbf{1 0 . 1}$ & $\mathbf{0 . 1 2}$ & $\mathbf{0 . 0 9}$ & $\mathbf{0 . 0 5 8}$ & $\mathbf{0 . 3 5}$ & $\mathbf{0 . 0 7}$ & $\mathbf{0 . 0 2 4}$ & $\mathbf{1 3 0}$ & $\mathbf{0 . 0 3}$ & $\mathbf{0 . 0 4}$ & 1.4 \\
\hline
\end{tabular}

Table 2 Final dose for particular internal parts

\begin{tabular}{|l|c|c|c|}
\hline Material & \multicolumn{3}{|c|}{ 08Kh18N10T } \\
\hline Origin & \multicolumn{3}{|c|}{ Greifswald I } \\
\hline Irradiated & $\mathbf{2 . 4} \mathrm{dpa}$ & $\mathbf{5 . 2} \mathrm{dpa}$ & $\mathbf{1 1 . 4} \mathrm{dpa}$ \\
\hline Component & Core barrel & Core baffle & Core former \\
\hline
\end{tabular}

\subsection{Testing specimen preparation and experimental program}

For the purpose of this project, unirradiated test specimens with dimensions of $12 \times 12 \times 60 \mathrm{~mm}$ were cut from the unirradiated block of austenitic stainless steel 08Kh18N10T (Figure 1). Irradiated miniaturized CT specimen with dimensions $10 \times 10 \times 4 \mathrm{~mm}$ (Figure 2) for testing of mechanical properties (especially hardness, fracture toughness) were cut from the original block 1 NPP's Greifswald of irradiated core barrel - AGS I (Figure 3) (WWER 440). Irradiated testing specimens were machined using by machine equipment located in hot cells Department of High Activity Laboratories and Irradiation Experiments (Figure 4).

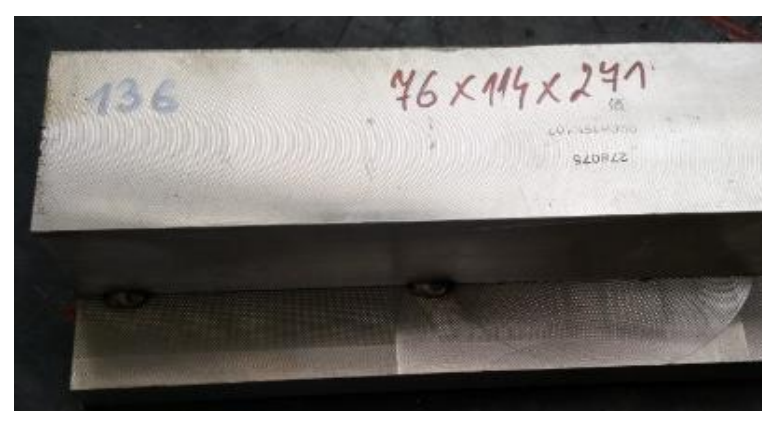

Figure 1 Unirradiated block of material of corrosion resistant austenitic stainless steel 08Kh18N10T

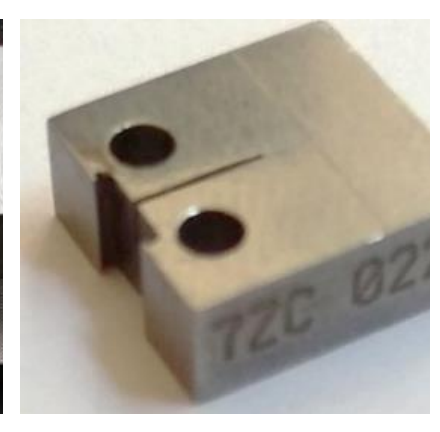

Figure 2 Miniaturized CT test specimen, UJV Rez, a. s.

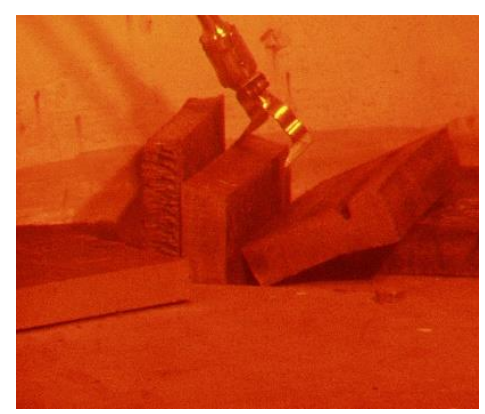

Figure 3 Irradiated samples from Greifswald I WWER 440 NPP 

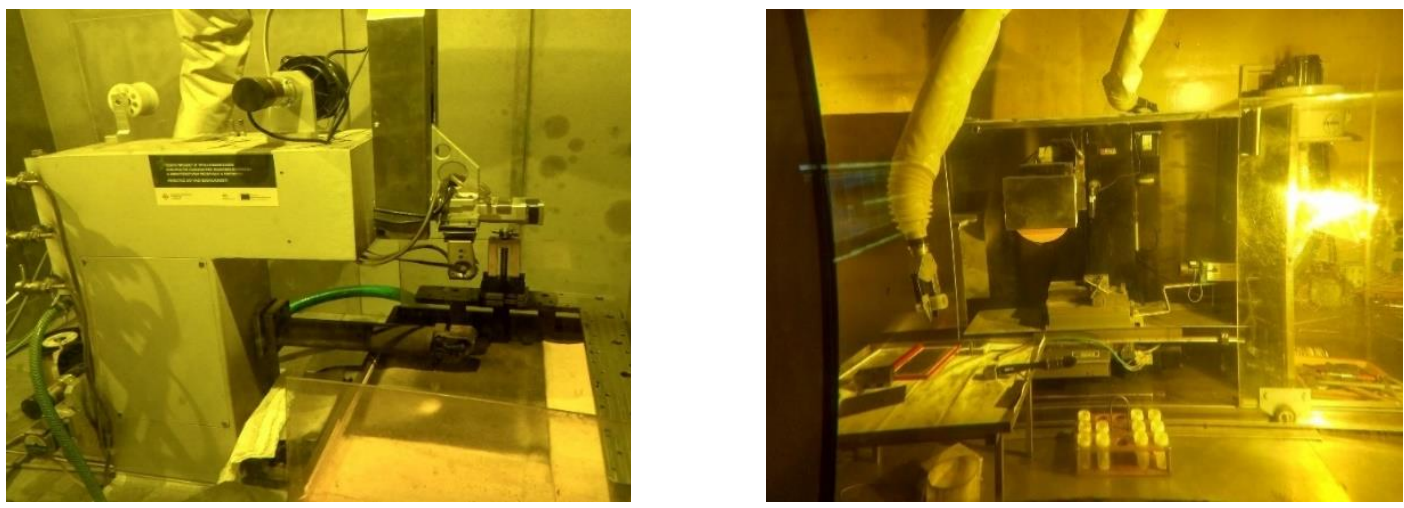

Figure $4 \mathrm{~A}$ - Electric discharge machining, B - Equipment for grinding of sample located in hot cell Department of High Activity Laboratories and Irradiation Experiments, UJV Rez, a. s.

\section{EXPERIMENTAL RESULTS AND DISCUSSION}

In the first step of the experimental program, the mechanical properties (especially hardness) unirradiated and irradiated specimen before and after thermal annealing was measured. For this project, the Vickers hardness test method HV5 was selected (CSN EN ISO 6507-1 Metallic materials - Vickers hardness test - Part 1). The hardness test measurements of irradiated test specimens were made on Zwick/Roell Indentec ZBH 30. This device is in semi-hot cell in the laboratory of Mechanical Testing Department, UJV Rez, a. s.

Based on the previous work by Petelova et. al. $(2018,2019)$ [4-6], two optimal thermal annealing regimes for unirradiated and irradiated testing specimen were selected: $550{ }^{\circ} \mathrm{C}$ and $600{ }^{\circ} \mathrm{C}$. Other process parameters were as follows: heating rate $-10^{\circ} \mathrm{C} / \mathrm{min}$, holding time $-1,2,4$ and 6 hours for unirradiated material, and 1 , 4, 6 hours for irradiated material, cooling - inside the furnace to room temperature, experiment duration approx. 24 hours, environment - air (2l per minute flow), specimen load - either one or several pieces, end of experiment $-50{ }^{\circ} \mathrm{C}$ or lower temperature. Laboratory of Mechanical Testing Department UJV Rez, a. s., is equipped with furnace (Figure 5), which is used for annealing of metallic materials in protective atmosphere at high temperatures.
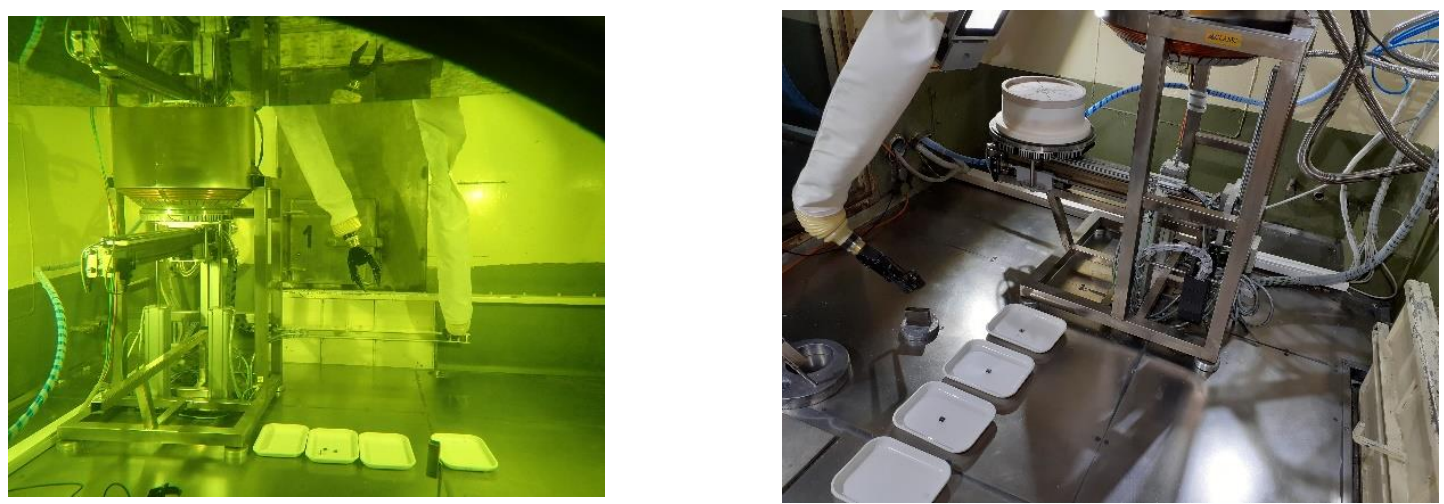

Figure 5 Annealing furnace located in hot cell - Laboratory of Mechanical Testing Department,

UJV Rez, a. s.

The hardness measuring results of unirradiated and irradiated material before and after thermal annealing are shown in Table 3 and Table 4. The influence of thermal annealing temperature and holding time on hardness test results of unirradiated and irradiated austenitic stainless steel 08Kh18N10T are graphically shown in Figure 6 and Figure 7. 
Table 3 The hardness test results of unirradiated corrosion resistant austenitic stainless steel 08Kh18N10T

\begin{tabular}{|c|c|c|}
\hline Thermal annealing temperature $\left[{ }^{\circ} \mathrm{C}\right]$ & Holding time $[\mathrm{h}]$ & Hardness HV 5 \\
\hline \multirow{2}{*}{550} & 1 & 171 \\
\cline { 2 - 3 } & 2 & 176 \\
\cline { 2 - 3 } & 4 & 173 \\
\cline { 2 - 3 } & 6 & 163 \\
\hline \multirow{2}{*}{600} & 1 & 173 \\
\cline { 2 - 3 } & 2 & 168 \\
\hline
\end{tabular}

Table 4 The hardness test results of irradiated corrosion resistant austenitic stainless steel 08Kh18N10T (core barrel, $2.4 \mathrm{dpa}$, Greifswald I)

\begin{tabular}{|c|c|c|c|}
\hline $\begin{array}{c}\text { Thermal annealing temperature } \\
{\left[{ }^{\circ} \mathbf{C}\right]}\end{array}$ & Holding time $[\mathrm{h}]$ & $\begin{array}{c}\text { Hardness HV 5 } \\
\text { (initial state) }\end{array}$ & $\begin{array}{c}\text { Hardness HV 5 } \\
\text { (thermal annealed) }\end{array}$ \\
\hline \multirow{3}{*}{50} & 1 & 249 & 230 \\
\cline { 2 - 4 } & 4 & 262 & 196 \\
\cline { 2 - 4 } & 6 & 292 & 231 \\
\hline \multirow{3}{*}{600} & 1 & 251 & 201 \\
\cline { 2 - 4 } & 4 & 286 & 183 \\
\cline { 2 - 4 } & 6 & 292 & 190 \\
\hline
\end{tabular}

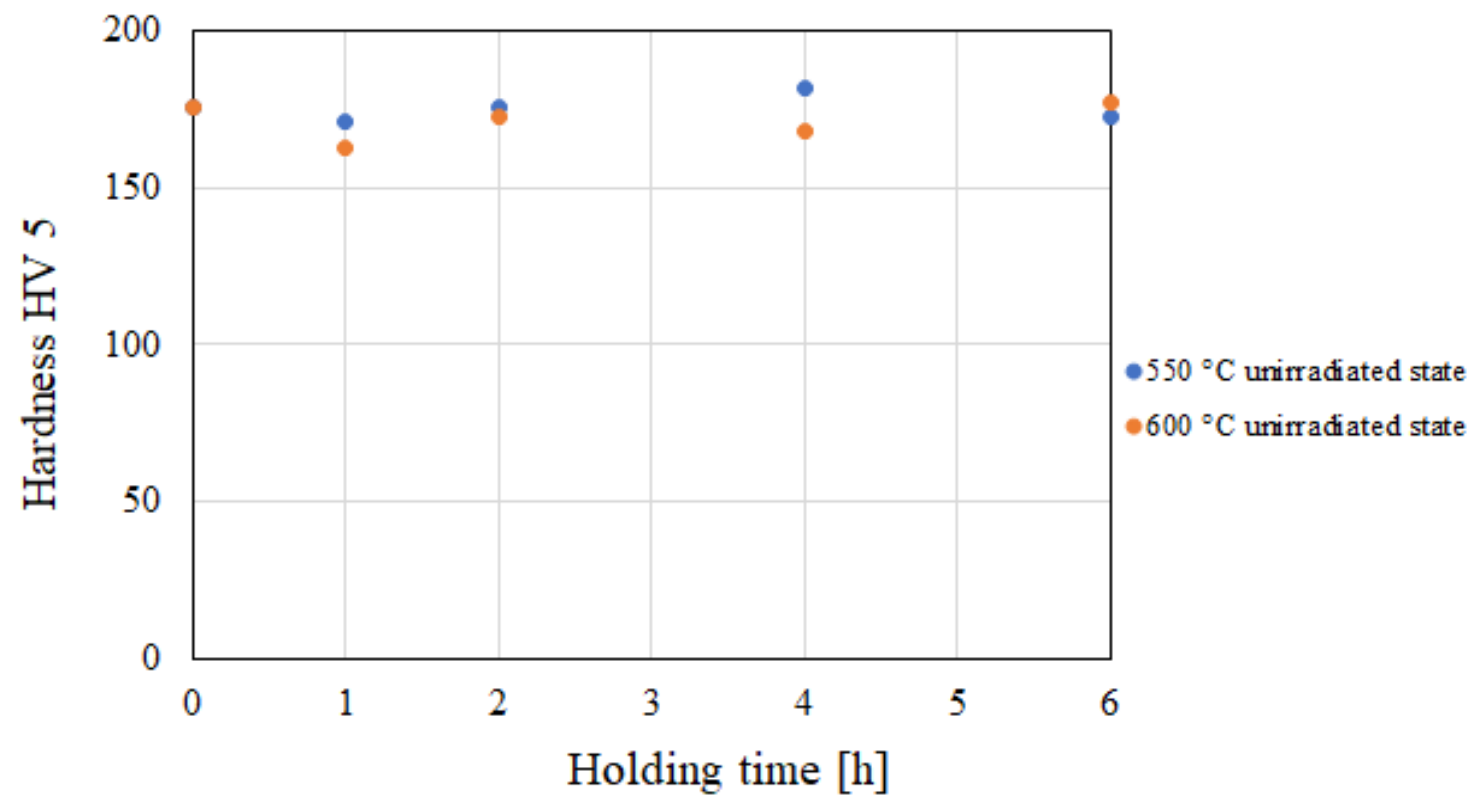

Figure 6 Comparison of hardness measurement results (HV 5) of unirradiated state of 08Kh18N10T steel two thermal annealing temperatures $550^{\circ} \mathrm{C}$ and $600^{\circ} \mathrm{C}$ 


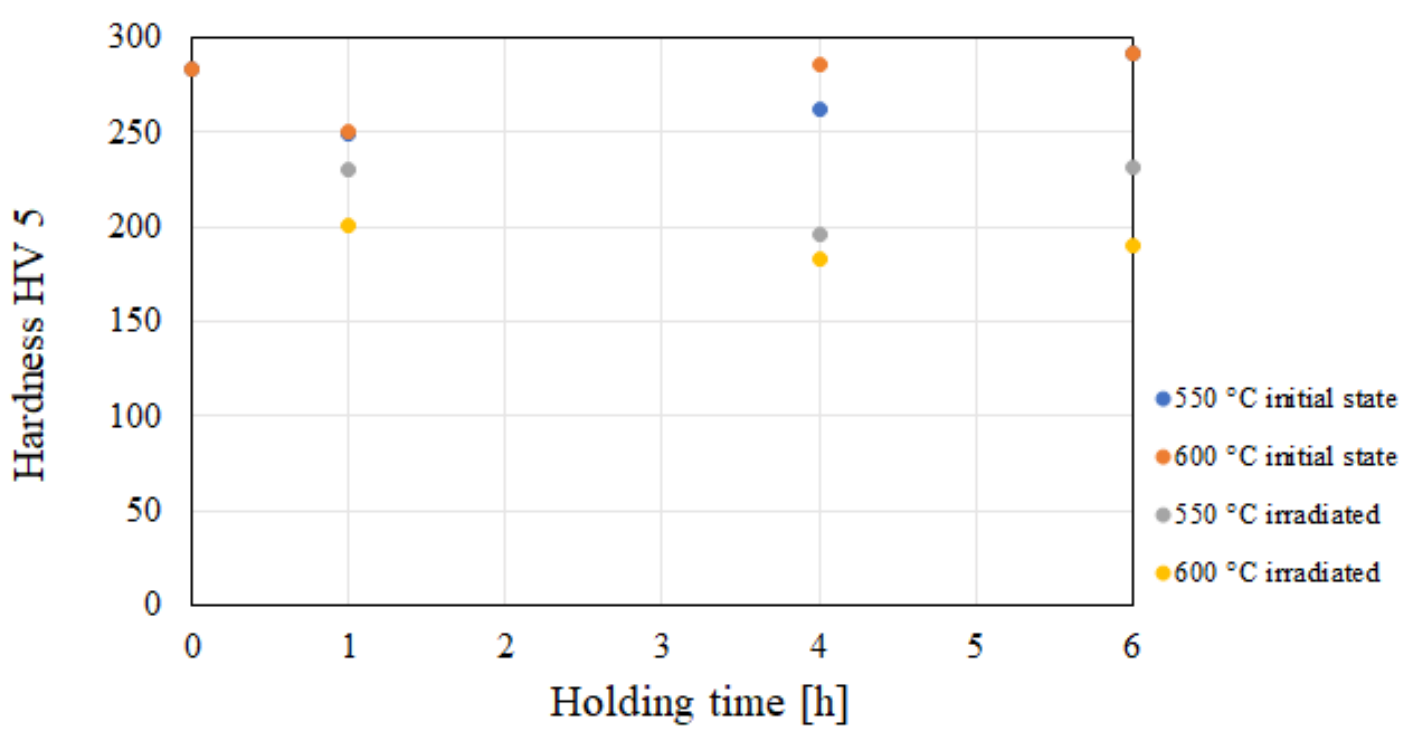

Figure 7 Comparison of hardness measurement results (HV 5) of irradiated state of 08Kh18N10T steel - two thermal annealing temperatures $550^{\circ} \mathrm{C}$ and $600^{\circ} \mathrm{C}$

Based on results of all experimental activities, the optimal annealing regime seems to be $600{ }^{\circ} \mathrm{C}$ with holding time 4 or 6 hours. This temperature demonstrated positive material response to the thermal annealing. The hardness of the irradiated material decreased from 295 HV 5 to 190 HV5. This value of hardness almost corresponds to initial state of unirradiated austenitic stainless steel $08 \mathrm{Kh} 18 \mathrm{~N} 10 \mathrm{~T}$.

\section{CONCLUSIONS}

The purpose of thermal annealing is the repair previous damage and to restore the initial properties of materials. This method can be applicable to WWER type RPVs' and internals with the aim of prolonging their lifetime. The experimental measurements of the effect of thermal annealing at $550{ }^{\circ} \mathrm{C}$ and $600{ }^{\circ} \mathrm{C}$ on mechanical properties of unirradiated and irradiated austenitic stainless steel $08 \mathrm{Kh} 18 \mathrm{~N} 10 \mathrm{~T}$ showed, that the optimal annealing regime is at $600{ }^{\circ} \mathrm{C}$ with holding time 4 and 6 hours. After thermal annealing at $600{ }^{\circ} \mathrm{C}$ with holding time 4 and 6 hours, decrease of hardness from 295 HV 5 to 190 HV 5 was observed. The next steps of the experimental activities will be:

- $\quad$ Thermal annealing and hardness measurement of irradiated miniature CT testing specimens cut from irradiated core baffle (5.2 dpa) and irradiated core former (11.4 dpa),

- $\quad$ Fracture toughness on miniature CT testing specimen (unirradiated and irradiated state and microstructural analysis of irradiated testing specimens before and after thermal annealing regime (core barrel, core baffle, core former).

At the present time there is no comparable method for reactor internals. After the completion of the project it will be possible to apply the results on reactor internals. The project will enable an introduction of a new certified methodology in the portfolio of the services offered to clients in the Czech Republic and abroad.

\section{ACKNOWLEDGEMENTS}

This paper includes results created within the projects supported by Technology Agency of the Czech Republic: TH02020565 „Assurance of Safe and Long-Term Operation of Nuclear Reactor Pressure Vessel Internals. 


\section{REFERENCES}

[1] INTERNATIONAL ATOMIC ENERGY AGENCY, Assessment and management of ageing of major nuclear power plant components important to safety: PWR vessel internals, IAEA-TECDOC-1119, ISSN 1011-4289, 1999.

[2] WAS, G. S. Fundamentals of Radiation Materials Science. Berlin Heidelberg New York: Springer, 2007.

[3] AMES - AGEING MATERIAL EUROPEAN STRATEGY: Ames report N. 19 [online] [viewed 2020-07-13]. Available from: https://publications.jrc.ec.europa.eu/repository/bitstream/JRC46534/eur23449\%20\%20ames\%2019\%20-\%20anneal-2008.pdf.

[4] PETELOVA P., et. al. Analyses of thermal annealing influence on WWER 440 reactor pressure vessel internals materials. In Metal 2019: 28th International Conference on Metallurgy and Materials. Ostrava: TANGER, 2019, pp. 787-792.

[5] PETELOVA P., et. al. Development of thermal annealing process of WWER-440 internals for providing a longterm operation, In Zvyšováni životnosti komponent energetických zařizeni v elektrárnách. PIzeň: University of West Bohemia, 2019, pp. 71-74.

[6] ELIASOVA I., et. al. Design of optimal thermal annealing regime of WWER-440 internals for providing a long-term operation, In Zvyšováni životnosti komponent energetických zařizení v elektrárnách. Plzeň: University of West Bohemia, 2019, pp. 227-232. 